\title{
Past and future ecosystem service trade-offs in Poyang Lake Basin under different land use policy scenarios
}

\author{
Hai Liu ${ }^{1,2,3} \cdot$ Liang Zheng ${ }^{2} \cdot$ Jing $\mathrm{Wu}^{2} \cdot$ Yonghao Liao $^{3}$ \\ Received: 12 April 2019 / Accepted: 6 December 2019 / Published online: 9 January 2020 \\ (C) The Author(s) 2020
}

\begin{abstract}
Poyang Lake is the largest freshwater lake in China and is an important wetland in the world. The scientific assessment of ecosystem service trade-offs in Poyang Lake Basin is of great significance for maintaining regional ecological balance and global biodiversity. This study uses land use as the main data source and the "equivalent factor method" to estimate the ecosystem service value of the Poyang Lake Basin from 1990 to 2015; the study also analyzes the trade-off synergy among ecosystem services. On this basis, land use information was simulated under three scenarios: planning scenario (government policyoriented), development scenario (economic benefit-oriented), and protection scenario (ecological protection-oriented). The trade-offs and synergies among ecosystem services under different scenarios were evaluated. The results demonstrate that the ecosystem service value for the entire basin steadily increased from 1990 to 2015. The relationships among ecosystem services in the basin were mainly synergistic, and there were few trade-offs. Among the three simulation scenarios, the ecosystem service value was the highest and the trade-offs among ecosystem services were the lowest under the protection scenario, the ecosystem service value was the lowest and the trade-offs among ecosystem services were the highest under the development scenario, and the trade-offs under the planning scenario were between the values of the protection scenario and the development scenario. From the perspective of maximizing the value of ecosystem services and minimizing trade-offs in ecosystem services, the protection scenario is the optimal scenario among the three scenarios.
\end{abstract}

Keywords Ecosystem services $\cdot$ Trade-off synergy $\cdot$ Scenario simulation $\cdot$ Poyang Lake Basin

\section{Introduction}

Ecosystem services refer to the natural environmental conditions and effects that human beings rely on to survive and sustain and all the benefits that humans receive directly or indirectly from ecosystems (Daily et al. 2009). This concept was first proposed by Wilson (Wilson and Matthews 1970) in

Hai Liu and Liang Zheng contributed equally to this work.

Responsible Editor: Haroun Chenchouni

Yonghao Liao

yh.liao77@outlook.com

1 School of remote Sensing and information, Wuhan University, Wuhan 430079, Hubei, China

2 Faculty of Resources and Environmental Science, Hubei University, Wuhan 430062, Hubei, China

3 Jiangxi Provincial Geomatics Center, Nanchang 330209, Jiangxi, China
1970. Thereafter, in 1997, Daily, the Editor-in-Chief of Nature's Services: Societal Dependence on Natural Ecosystems (Daily 1997), and the Value of the World's Ecosystem Services and Natural Capital (Costanza et al. 1997), published in Nature by Costanza et al., made the study of ecosystem services' value a hot topic in International Ecology and Eco-economics. In 2000, the United Nations launched the Millennium Ecosystem Assessment project (MA) (Millennium Ecosystem Assessment 2005), which led to the development of integrated ecosystem assessments. Due to the limitations of the MA in value assessment and practical application, some scholars have begun to re-examine the ecosystem services classification system in recent years (Pandeya et al. 2016; Mcdonough et al. 2017; Costanza et al. 2017). At present, the classification system of the MA is the most influential in the study of ecosystem services classification (Brauman et al. 2007; Haines-Young and Potschin 2009). In this study, the value of ecosystem services is divided into four categories, namely, supply, regulation, culture, and support functions. A paradigm for evaluating the value of ecosystem 
services is proposed, and the interdependence between ecosystem services and human well-being is pointed out. With the deepening of research on ecosystem services, the importance of conducting coordinated research on ecosystem service trade-offs has become increasingly prominent.

The relationships among ecosystem services include trade-offs, synergies, and compatibilities (Willemen et al. 2010). Due to the diversity of ecosystem services, the imbalance of spatial distribution, and the selectivity of human use, the relationships among ecosystem services have changed dynamically, which is expressed in the form of trade-offs and synergies of mutual gains (Barbier et al. 2008). Among them, "trade-offs" refer to the situation in which the supply of one type of ecosystem services decreases due to the increase in the use of other types of ecosystem services, which generally exists between support services and regulatory services (Rodríguez et al. 2006). "Synergy" refers to the situation in which two or more types of ecosystem services increase or decrease simultaneously, mainly in support services and text. It also regulates the relationship between ecosystem services and cultural services (Fu and $\mathrm{Yu}$ 2016). The growth of ecosystem services is related to the diversity of ecosystem services, the imbalance of spatial distribution, and the selectivity of human use. To reduce the negative effects of trade-offs, it is necessary to conduct a trade-off analysis of ecosystem services before making decisions (Naidoo et al. 2008). Synergy is the internal way to maximize the benefits of ecosystem services and the ultimate goal of human social development (Li et al. 2012). Recognizing the interrelationship among ecosystem services and clarifying their spatial and temporal characteristics and driving mechanisms can coordinate and optimize multiple services and avoid harming other services while improving one service. It is of great significance for promoting the sustainable management of regional ecosystems, guiding the rational development of natural resources and improving human well-being. It is also the key link for ecosystem services between theoretical research and management practices (Peng et al. 2017). At present, the relationship between ecosystem services has become a hot topic in the study of ecosystem services. Many scholars have conducted in-depth studies on the trade-offs and synergies of ecosystem services, including the definition, types, temporal changes and spatial scale effects, research methods, driving mechanisms, research significance, and corresponding measures (Peng et al. 2017) (Bennett and Balvanera 2007; Bennett et al. 2009; Cord et al. 2017). Under the background of the deteriorating ecological environments in Poyang Lake Basin, it is necessary to correctly understand the multiple nonlinear relationships, characteristics, response rates, driving mechanisms, and scale effects between ecosystem services (Dai et al. 2016) to determine the ecological statuses of different ecosystem types, regions, and levels.

In recent years, research on the trade-offs and synergies of ecosystem services has increased. From qualitative research to quantitative analyses, the research mainly includes the identification and expression of trade-offs and synergies. The commonly used analytical methods in related research include the following: statistical analyses (Kain et al. 2016), spatial analyses (Sun and Li 2017), model simulations (Byron et al. 2015), and scenario analyses (Butler et al. 2013). Among these four methods, the data for statistical analyses are generally from government departments and observation stations. This method can simply and quickly analyze the correlation of ecosystem services, but cannot better express the spatial differences and connections of ecosystem services. Spatial analyses have advantages of analyzing the spatial distribution of ecosystem services, which is helpful for analyzing their trade-offs and synergies. Based on geography and ecology theories, model simulations can establish an integrated eco-economic model (Byron et al. 2015), which ultimately puts forward a planning plan that meets the objective requirements through multi-objective optimization. Higgins et al. (1997) analyzed the impact of alien species invading shrub communities on ecosystem services based on this model. Chisholm et al. (Chisholm 2010) dynamically analyzed the relationship among water supply, carbon sequestration, and wood production of Pinus radiata. Hussain et al. (Hussain and Tschirhart 2013) analyzed the trade-offs among biodiversity, grazing, and hunting, and pointed out that if spatial-temporal heterogeneity is taken into account, the results of the model analysis will be closer to the reality. Due to its mature development, this model has been widely used in research. However, this method is mostly used to analyze the trade-offs among market-oriented ecosystem services and has obvious disadvantages when it comes to the study of trade-offs and synergies among ecosystem services that focus on "public goods." In addition, the method produces a large amount of data, and the research scale is usually small ( $\mathrm{Ziv}$ et al. 2012). Scenario analyses are based on certain land use patterns, combined with relevant ecological and economic policies, to simulate a variety of scenarios in order to understand the trade-offs and synergies between services under the corresponding scenarios (Alcamo et al. 2005). However, this method is not mature, the accuracy of the research results need to be verified, and it is not widely used for guiding policy-making (Tallis and Polasky 2009). In addition, the method is limited by data acquisition, the calculation model, index construction, and other factors, and the number of ecosystem services selected is also limited. Therefore, quantitative and evaluation research on the dynamic relationship between the overall benefits 
of ecosystem services and the benefits of a single service is insufficient ( $\mathrm{Li}$ et al. 2012).

Ecosystem service trade-offs are generally related to changes in landscape patterns, and regional landscape patterns are closely related to regional policies and natural factors. The scenario simulation method can help decision-makers create regional development plans to maximize the benefits of ecosystem services by establishing a set socioeconomic conditions and ecological protection scenarios and analyzing the impact mechanisms of government policies, human activities, and landscape pattern changes on the relationship between ecosystem services (Haase et al. 2012). Therefore, this study uses a scenario simulation method to analyze the trade-offs and synergies among regions.

Poyang Lake is the largest freshwater lake in China, an internationally important wetland, the largest migratory bird habitat in Asia, rich in biodiversity and species resources, and one of the key areas for global water security and biodiversity conservation. It is of great significance for maintaining regional ecological balance and maintaining global biodiversity (Liu et al. 2017a, b; Shankman et al. 2006). However, in recent years, due to changes in water storage in upstream reservoirs and climate change (Tu and Long 2015), the ecological environment of Poyang Lake Basin has faced several crises, the wetland vegetation has been seriously degraded and the ecosystem services and biodiversity of the river basins have become seriously threatened (Hua et al. 2016). Therefore, scientific evaluation of the ecosystem service value and its dynamic relationship in the Poyang Lake Basin is of great significance to the ecological protection of the basin. At present, research on ecosystem services in Poyang Lake Basin is mainly focused on value assessments (Wang et al. 2007; Liu et al. $2017 \mathrm{a}, \mathrm{b}$ ), while research on trade-off coordination is relatively limited. Therefore, this paper takes Poyang Lake as the research area and uses land use as the main data source. The "equivalent factor method" is used to analyze the dynamic changes in the service values of different ecosystems over a continuous time series from 1990 to 2015 and the trade-off synergies in these ecosystems. On this basis, the land use under three different scenarios (plan, protection, and development scenarios) is simulated using the 2015 land use data as the base period data and the relevant policies in the Poyang Lake Basin, and the ecosystems under different scenarios are simulated. The ecosystem services and their trade-offs are evaluated and analyzed. Finally, the measures required for maximizing the benefits of ecosystem services in the Poyang Lake Basin are proposed.

\section{Materials and data}

Poyang Lake is located in southern China on the south bank of the middle and lower reaches of the Yangtze River. Poyang
Lake is connected to the Lancang, Xiushui, Raohe, Xinjiang, and Fuhe Rivers. It is an important reservoir lake in the Yangtze River and plays a tremendous role in flood regulation and the protection of biodiversity in the Yangtze River Basin of China. At the same time, Poyang Lake is also one of the most important ecological zones designated by the World Wide Fund for Nature (Finlayson et al. 2010). This lake has an irreplaceable ecological status in the global ecological pattern. In addition, the Poyang Lake Basin $\left(24^{\circ} 24^{\prime} \mathrm{N}-29^{\circ} 46^{\prime}\right.$ $\mathrm{N}, 113^{\circ} 23^{\prime} \mathrm{E}-118^{\circ} 46^{\prime} \mathrm{E}$ ) has a total area of $162,000 \mathrm{~km}^{2}$. The Poyang Lake Basin is located within the boundaries of Jiangxi Province, accounting for $97 \%$ of the total area of the lake. This area is an ideal place to conduct research on the relationship between river basins and people. The basin belongs to the subtropical humid monsoon climate. The annual average temperature is $17.9^{\circ} \mathrm{C}$, the annual average rainfall is $1642 \mathrm{~mm}$, the basin is surrounded by mountains on three sides, the middle of the terrain is low, and the surrounding terrain is high (Zhao et al. 2017). With the approval of the "Poyang Lake Ecological Economic Zone Plan" by the State Council of China on December 12, 2010, the ecological construction in the basin has risen to China's national standards (Xie et al. 2018) (Fig. 1).

The main data used in this study include land use data from 1990 to 2015 and net primary productivity (NPP) simulation data for Poyang Lake Basin (Field et al. 1998), which were

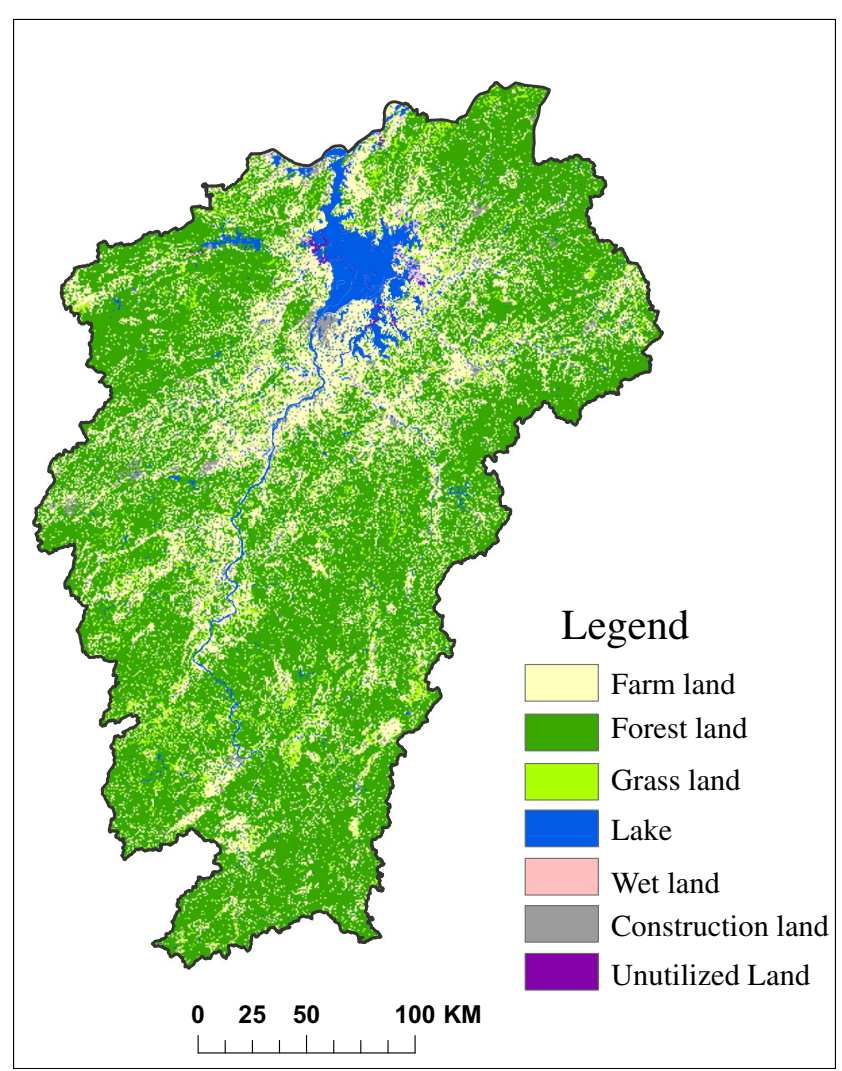

Fig. 1 Land use types of the Poyang Lake Basin in 2015 
acquired from the China National Earth System Science Data Sharing Platform (www.geodata.cn). The national planting areas of rice, wheat, and corn and the income and expenditure per unit area were derived from the China Statistical Yearbook (National Statistical Bureau of the People's Republic of China) and the National Agricultural Products Cost-benefit Data Collection (National Development Planning Commission). The national and farmland grain output per unit area was acquired from the China Statistical Yearbook (National Statistical Bureau of the People's Republic of China) and Jiangxi Provincial Statistical Yearbook (Statistical Bureau of Jiangxi Province, China).

\section{Methods}

\section{Land use scenario simulation}

\section{Markov model}

The Markov model (Guan et al. 2008) is a stochastic model that is mainly used to model land use change. In the Markov process, the state of the system is related to only the current state. The Markov model describes the land use change from one period to another. Based on this, future trends in land use change are predicted (Hua et al. 2016). The formula is as follows:

$S_{t+1}={ }^{t+1} P_{i j} S_{t}$

$S_{t}$ and $S_{t+1}$ are the states of the land use system at time $t$ and $t+1$, respectively; $P_{i j}$ is the state transition matrix.

The cellular automaton (CA) model has powerful spatial computing power (Saeed 1986), which is a grid dynamics model with discrete times, spaces, and states as well as spatial interaction and time causality. The CA model has the ability to simulate the spatiotemporal evolution process of complex systems (Wang et al. 2007) and is as follows:

$S_{t+1}={ }^{t+1} f\left(S_{t}, N\right)$

$S$ is a finite and discrete set of states of the cell; $N$ is the neighborhood of the cell; $t$ and $t+1$ are different moments; $f$ is the cell transformation rule of the local space.

In this paper, the Markov model is combined with the CA model, and the spatial weighting factor is added to the Markov model, which can simulate complex spatial and temporal changes as well as provide long-term predictions of land use (Wang et al. 2017). First, by calculating the transfer matrix of land use in multiple periods, the probability of a land use type occurring in each grid unit is determined, and the spatial distribution of the probability of land use types is obtained. Then, according to different scenario setting requirements, the transfer matrix is modified to obtain the transfer matrix under different scenarios. The land use raster data of the Poyang Lake Basin in 2015 and the transfer matrix of different scenarios are input into the CA-Markov model to obtain different land use data prediction for the Poyang Lake Basin in 2030.

\section{Different land use simulation scenarios}

The scenario analysis method assumes that a certain phenomenon can continue into the future and uses this information to predict the future situation and consequences. The land use scenario simulation in this study was conducted to determine the socioeconomic development status and ecological protection objectives in certain periods of time (history, current stage, or future), simulate the corresponding land use scenarios as background variables, and evaluate the changes in ecosystem services and the mutual relationship changes (Xie et al. 2015).

By integrating the various policy measures currently formulated for the land use requirements in Poyang Lake Basin, the scenario plan is created by correcting the transfer probability and related parameters between different land use types. This paper sets three land use scenarios: protection, planning, and development scenarios (Nelson et al. 2009). The meanings of the different scenarios are as follows:

Protection scenario: This scenario has the primary goal of protecting the ecological security and biodiversity of the Poyang Lake Basin. Referring to relevant research results (Hua et al. 2016), the probability of transfer from cultivated land to construction land is reduced by $25 \%$, the probability of transfer from forestland, wetland, and water area to construction land is reduced by $90 \%$, and the probability of transfer from forestland to cultivated land is reduced by $50 \%$ (Saeed 1986). At the same time, to enhance the availability of ecosystem services by restoring the lost ecological potential, cultivated land with a slope of $25^{\circ}$ or more is converted into forest and grassland to strengthen the ecological construction of the wetlands and ecological reserves to ensure biodiversity in the basin (Table 1).

Planning scenario: The land use forecast under this scenario is mainly based on government documents such as the Jiangxi Population Development Plan (2016-2030), the Jiangxi Provincial Land Use Master Plan (2006-2020), and the National Land Plan (2016-2030). According to the targets for cultivated land and construction land, the areas of cultivated land and construction land in the Poyang Lake Basin in 2030 are derived. The Markov transition probability matrix is then modified to obtain the land use data for the 2030 planning scenario (Table 2).

Development scenario: Under this scenario, the land use demands in Poyang Lake Basin are basically not affected by policy regulation, and the land use patterns and quantities 
Table 1 Land transfer matrix under the protection scenario

\begin{tabular}{llllllll}
\hline Area & Farmland & Forestland & Grassland & Lake & Wetland & Construction land & Unutilized land \\
\hline Farmland & 37,642 & 3293 & 1103 & 2102 & 694 & 30 & 0 \\
Forestland & 34 & 105,097 & 83 & 4 & 124 & 0 & 0 \\
Grassland & 45 & 1028 & 6441 & 44 & 0 & 0 & 0 \\
Lake & 290 & 76 & 48 & 5790 & 180 & 601 & 0 \\
Wetland & 435 & 210 & 0 & 45 & 3570 & 0 & 0 \\
Construction land & 9 & 0 & 0 & 133 & 0 & 509 & 17 \\
Unutilized land & 0 & 0 & 0 & 0 & 0 & 0 & 0 \\
\hline
\end{tabular}

change according to the trends before 2015. Among these changes, the cultivated land, forestland, and water areas showed a trend of continuous decline, the wetland areas showed a trend of increasing slowly, and the construction land showed a rapid growth trend (Table 3 ).

\section{Estimation of ecosystem services}

\section{Ecosystem service classification}

In this paper, the classification of ecosystem services is based on the classification method of the MA (Millennium Ecosystem Assessment), which divides ecosystem services into supply services, regulation services, and cultural services. In addition, considering that the water supply of Poyang Lake is an important function, the supply of water resources is added as a supply service, and on this basis, the ecosystem services are further divided into eight subcategories (Table 4).

\section{Ecosystem service value assessment method}

The spatial distributions of ecosystems and ecosystem service types are heterogeneous. Costanza (Costanza et al. 1997) estimated the value of global ecosystem services as only a global average, which when applied to regional scales, can lead to large errors. For that reason, Xie Gaidi and colleagues at the Institute of Geographic Science and Natural Resources Research CAS revised the ecosystem services equivalent value per unit area based on a questionnaire survey of 700 professional personnel with ecology backgrounds and according to China's ecological systems and social-economic development. Based on the output and area of farmland grain per unit area in 2010, they calculated the Chinese standard unit equivalent factor for the current year, determining that the ecosystem service value of China's standard unit equivalent factor was 481.19 yuan/ha. Based on the calculation results of Xie et al. in 2010, this study revised the ecological service value per unit area for the Poyang Lake Basin (Xie et al. 2008).

\section{Correction of the value of ecosystem services per unit area}

Both the temporal and spatial components of the calculation results of Xie Gaodi et al. (2010) were revised. For the spatial component, this paper uses the ratio of the grain yield per unit area of the study area to the yield per unit area of grain farmland in China as the revised coefficient and revises the ecosystem service value per unit area to the ecosystem service value per unit area of the Poyang Lake Basin. For the temporal component, the service value per unit area of the Poyang Lake Basin is revised each year using the grain yield data per unit area of the corresponding year (Table 5).

In addition, considering the close relationship between biomass and ecosystem services, this paper uses NPP to modify the ecosystem service value of Poyang Lake Basin on the basis of regional correction and evaluates certain pixels in the study area. The NPP value $\left(\mathrm{NPP}_{i j}\right)$ is compared with the NPP average of the type of ecosystem to which the pixel

Table 2 Land transfer matrix under the planning scenario

\begin{tabular}{llllllll}
\hline Area & Farmland & Forestland & Grassland & Lake & Wetland & Construction land & Unutilized land \\
\hline Farmland & 38,053 & 3293 & 760 & 1302 & 1426 & 30 & 0 \\
Forestland & 1920 & 100,334 & 2426 & 338 & 324 & 0 & 0 \\
Grassland & 45 & 1028 & 6184 & 44 & 257 & 0 & 0 \\
Lake & 290 & 76 & 98 & 5940 & 180 & 401 & 0 \\
Wetland & 435 & 210 & 0 & 45 & 3570 & 0 & 0 \\
Construction land & 9 & 0 & 0 & 133 & 0 & 509 & 0 \\
Unutilized land & 0 & 0 & 0 & 0 & 0 & 0 & 17 \\
\hline
\end{tabular}


Table 3 Land transfer matrix under the development scenario

\begin{tabular}{llllllll}
\hline Area & Farmland & Forestland & Grassland & Lake & Wetland & Construction land & Unutilized land \\
\hline Farmland & 37,722 & 893 & 91 & 1002 & 5226 & 30 & 0 \\
Forestland & 1920 & 90,358 & 6426 & 338 & 6300 & 0 & 0 \\
Grassland & 45 & 1028 & 6184 & 44 & 257 & 0 & 0 \\
Lake & 290 & 76 & 48 & 5790 & 180 & 601 & 0 \\
Wetland & 435 & 210 & 0 & 45 & 3570 & 0 & 0 \\
Construction land & 9 & 0 & 0 & 133 & 0 & 509 & 0 \\
Unutilized land & 0 & 0 & 0 & 0 & 0 & 0 & 17 \\
\hline
\end{tabular}

belongs, and the ratio is used as a functional factor to dynamically adjust the element based on the function factor (Xie et al. 2015).

$p_{i}=\mathrm{NPP}_{i} / \mathrm{NPP}_{i j \text { mean }}(i=1995 \cdots 2015)(j=1,2 \cdots)$

$p_{i}$ represents the functional adjustment factor for the $i$-th year; $\mathrm{NPP}_{i j}$ represents the NPP value of a certain pixel in the $i$-th year; $\mathrm{NPP}_{i j \text { mean }}$ represents the average value of the NPP of the $j$-th ecosystem in the $i$-th year.

\section{Ecosystem service value calculation model}

After the correction of the ecosystem service value per unit area, combined with the basic equivalent tables of different types of ecosystems and different types of ecosystem service functions, the ecosystem service values per unit area for the different land types are obtained for the different years in the study area. The land use data, the total value of ecosystem services in the study area, and the calculation model are as follows:

$\mathrm{ESV}=\sum_{i=1}^{n} S_{i} \times \mathrm{VC}_{i}$

ESV is the total ecosystem service value, $S_{i}$ is the area of the $i$-th land use type in the study area, $\mathrm{VC}_{i}$ is the ecosystem service value per unit area of the $i$-th land use type, and $i$ is the land use type.

\section{Research methods for trade-off and synergy}

Spatially, the pixel-by-pixel correlation of temporal and spatial statistical mapping methods is used to quantitatively assess the interrelationships between ecosystem

Table 4 Classification of ecosystem services

\begin{tabular}{|c|c|c|}
\hline \multicolumn{2}{|c|}{ Classification of ecosystems } & \multirow{2}{*}{$\begin{array}{l}\text { Definition/use of the services } \\
\text { Food products from plants, animals, and microorganisms. }\end{array}$} \\
\hline Supply service & Food production & \\
\hline & Raw material production & $\begin{array}{l}\text { Raw production (for example, wood, jute, hemp, silk, and other products) } \\
\text { from plants, animals, and microorganisms. }\end{array}$ \\
\hline & Water supply & $\begin{array}{l}\text { Refers to the water resources provided by the ecosystems and used for } \\
\text { residential life, agriculture (irrigation), and industrial processes. }\end{array}$ \\
\hline \multirow[t]{4}{*}{ Adjustment service } & Gas regulation & $\begin{array}{l}\text { Ecosystems release chemicals into the atmosphere and also absorb chemicals } \\
\text { from the atmosphere, which can have multifaceted effects on gas. }\end{array}$ \\
\hline & Climate regulation & $\begin{array}{l}\text { The ecosystem has an impact on both the local climate and the global climate. } \\
\text { For example, on the local scale, the change of land use can affect the temperature } \\
\text { and precipitation. On the global scale, ecosystems play an important role in the } \\
\text { climate through the absorption and emission of greenhouse gases. }\end{array}$ \\
\hline & Environment purification & $\begin{array}{l}\text { The vegetation and organisms in ecosystems to degrade excess nutrients and } \\
\text { compounds, the retention of dust, decontamination, and other functions. }\end{array}$ \\
\hline & Hydrological regulation & $\begin{array}{l}\text { The timing and size of runoffs and floods and the recharging of aquifers are } \\
\text { strongly influenced by changes in land cover, especially activities that alter } \\
\text { the water storage potential of the system, such as the conversion of wetlands, } \\
\text { the conversion of forests to farmland, or the conversion of farmland to city. }\end{array}$ \\
\hline Cultural service & Esthetic landscape & $\begin{array}{l}\text { People can find esthetic value in many aspects of ecosystems, which is already } \\
\text { reflected in their love of parks, boulevards, and their choices of housing locations. }\end{array}$ \\
\hline
\end{tabular}


Table 5 Different equivalent values in different years for the Poyang Lake Basin (unit: yuan/ha)

\begin{tabular}{lll}
\hline Equivalent factor & China & Poyang Lake Basin \\
\hline 1990 & 356.74 & 406.42 \\
1995 & 383.24 & 414.39 \\
2000 & 404.80 & 461.72 \\
2005 & 449.10 & 509.69 \\
2010 & 481.19 & 519.68 \\
2015 & 530.46 & 561.03 \\
2030 & 575.28 & 614.93 \\
\hline
\end{tabular}

services. The correlation is calculated as follows (Wang et al. 2017; Xu 1996):

$r=\frac{\sum_{n=1}^{n}\left(\mathrm{ES}_{n(i j)}-\overline{\mathrm{ES}_{(i j)}}\right)\left(\mathrm{ES} 2_{n(i j)}-\overline{\mathrm{ES}_{(i j)}}\right)}{\sqrt{\sum_{n=1}^{n}\left(\mathrm{ES}_{n(i j)}-\overline{\mathrm{ES}_{(i j)}}\right)^{2}\left(\mathrm{ES}_{n(i j)}-\overline{\mathrm{ES}_{(i j)}{ }^{2}}\right)}}$

ES1 and ES2 represent two different ecosystem services; $r$ is the correlation coefficient between $\mathrm{ES} 1$ and $\mathrm{ES} 2 ; i$ and $j$ represent the row and column numbers of specific pixels in the raster data, respectively; $n$ is the grid time series of the data. The correlation coefficient between ES1 and ES2 was calculated, and a $t$ test was used to evaluate the significance of the relationship between ecosystem services; single asterisk (*) indicates that ES1 is significantly correlated with ES2 at the 0.05 level, and double asterisk (**) indicates that ES1 is significantly correlated with ES2 at the 0.01 level. The correlation coefficients between -0.2 and 0.2 are not considered to be correlated.

\section{Results}

\section{Changes in the value of ecosystem services and their relationship in Poyang Lake Basin}

\section{Changes in the value of ecosystem services in the Poyang Lake Basin}

The value of ecosystem services in the Poyang Lake Basin from 1990 to 2015 showed a significant increasing trend, from 144.341 billion yuan to 1990.77 billion yuan, a total increase of 54.736 billion yuan. The largest increase occurred from 1995 to 2000 , and the second highest increases occurred from 2000 to 2005 . The smallest annual increase occurred from 1990 to 1995 . The dominant ecosystem services are regulating and supply services, accounting for approximately $85 \%$ and $9 \%$ of the ecosystem service values, respectively. The lowest ecosystem services are cultural services, accounting for only approximately $6 \%$ of the ecosystem service values (Table 6 ).

The values of ecosystem services in the Poyang Lake Basin in $1990,1995,2000,2005,2010$, and 2015 were calculated according to the values of the six categories, and a distribution map of the ecosystem service values was obtained. This figure shows that except for Poyang Lake, the value of ecosystem services in the basin is low in the middle and high in the surrounding areas. The areas with high ecosystem service values are distributed in Poyang Lake and parts of the northwest. Areas with low ecosystem service values are more consistent with farmland and construction land, which are mainly located in the central and southern parts of the country. The median ecosystem service values are mainly distributed in parts of the central and western regions (Fig. 2).

\section{Watershed ecosystem service trade-off synergy from 1990 to 2015}

Based on the values of various types of ecosystem services in the Poyang Lake Basin in different periods, the correlation between the eight ecosystem services was obtained through correlation analysis. The results show that the synergistic relationship is the dominant relationship between the ecosystem services in the Poyang Lake Basin, accounting for $59.37 \%$. Collaborative relationships are mainly found in supply and cultural services and in regulating relationships with other types of ecosystem services (Table 7).

In terms of supply services, there is a significant positive correlation between food production and raw material production among three different types of supply services, while there is no significant negative correlation between food production and water supply, or between raw material production and water supply. The relationship between supply services and other services is as follows: food production is negatively correlated with environment purification and hydrological regulation, and positively correlated with other services. There is a negative correlation between raw material production and hydrological regulation, and a positive correlation with other services. Water supply is positively correlated with environment purification and hydrological regulation, and negatively correlated with other services.

Among the four different types of regulation services, climate regulation and gas regulation are positively correlated, while they are negatively correlated with environmental purification and hydrological regulation. The relationship between regulation services and other services is as follows: both gas regulation and climate regulation are negatively correlated with the water resources supply and positively correlated with other services. There is a negative correlation between environmental purification and food production, and a positive correlation with other services. Hydrological regulation is 
Table 6 Ecosystem service values in the Poyang Lake Basin (100 million yuan)

\begin{tabular}{|c|c|c|c|c|c|c|c|}
\hline \multicolumn{2}{|l|}{ Year } & \multirow{2}{*}{$\begin{array}{c}1990 \\
38.40\end{array}$} & \multirow{2}{*}{$\begin{array}{c}1995 \\
39.21\end{array}$} & \multirow{2}{*}{$\frac{2000}{43.54}$} & \multirow{2}{*}{$\frac{2005}{47.92}$} & \multirow{2}{*}{$\begin{array}{l}2010 \\
48.77\end{array}$} & \multirow{2}{*}{$\begin{array}{l}2015 \\
52.32\end{array}$} \\
\hline Supply service & FP & & & & & & \\
\hline & $\mathrm{RP}$ & 33.26 & 33.98 & 37.76 & 41.57 & 42.43 & 45.59 \\
\hline & WS & 3.35 & 1.59 & 3.94 & 4.87 & 5.02 & 6.02 \\
\hline \multirow[t]{4}{*}{ Regulation service } & GR & 117.68 & 120.36 & 133.57 & 146.98 & 149.98 & 161.13 \\
\hline & $\mathrm{CR}$ & 303.75 & 310.53 & 344.93 & 379.93 & 387.91 & 416.88 \\
\hline & $\mathrm{ED}$ & 105.29 & 106.71 & 119.58 & 131.83 & 134.51 & 144.86 \\
\hline & HA & 539.06 & 532.63 & 613.28 & 681.77 & 693.44 & 749.98 \\
\hline Cultural service & $\mathrm{AL}$ & 55.60 & 56.50 & 63.09 & 69.03 & 70.56 & 75.89 \\
\hline Total & & 1443.41 & 1453.55 & 1640.05 & 1811.80 & 1847.13 & 1990.77 \\
\hline \multicolumn{2}{|c|}{ The rate of change from the previous period to the later period (\%) } & - & 0.70 & 12.83 & 10.47 & 1.95 & 7.77 \\
\hline
\end{tabular}
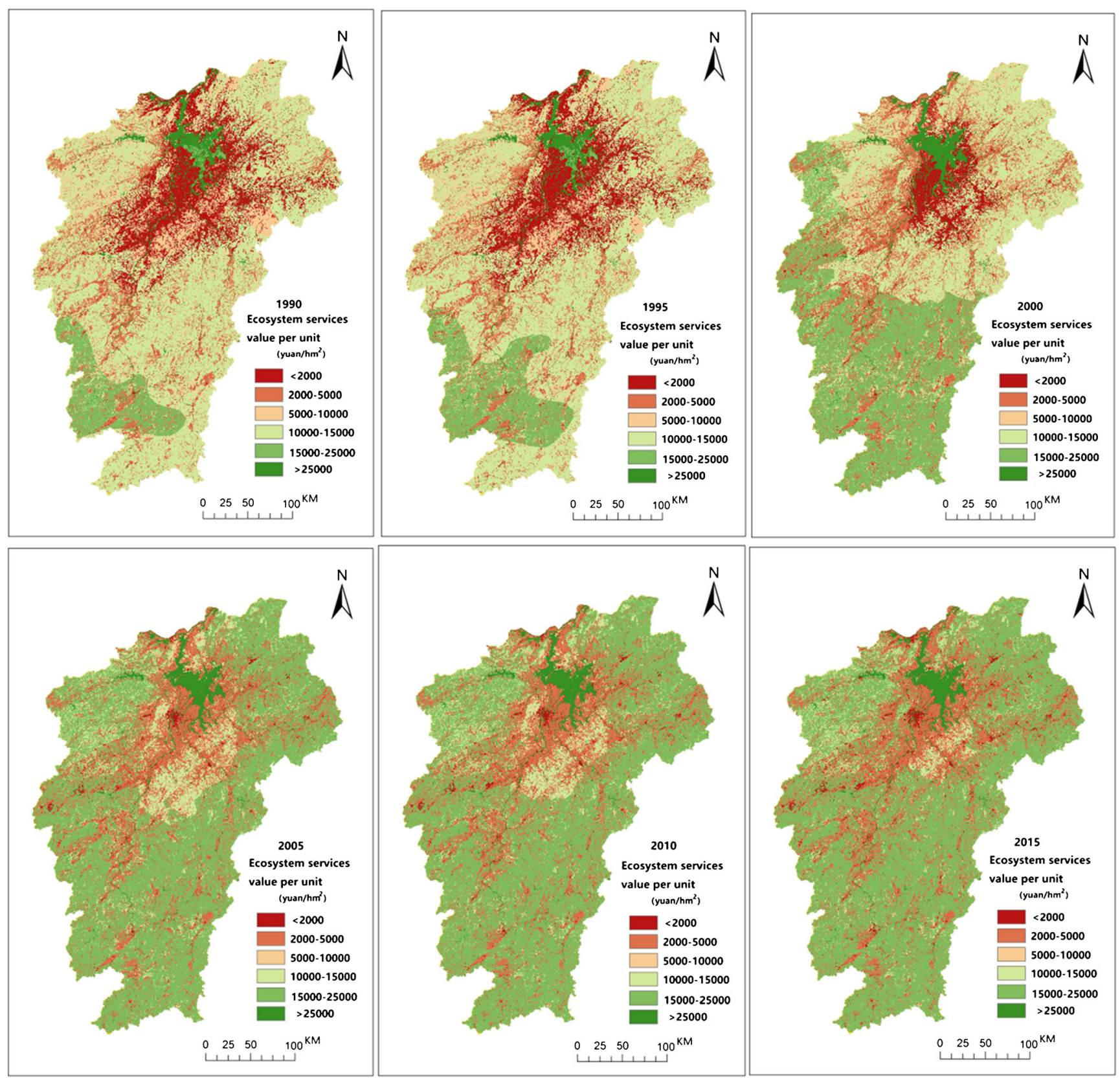

Fig. 2 Distribution of ecosystem service value over the years (unit: yuan/ha) 
Table 7 Trade-offs and synergies among ecosystem services in the Poyang Lake Basin

\begin{tabular}{clllllll}
\hline Related & FP & RP & WS & GR & CR & ED & HA \\
\hline FP & 1 & $0.966^{* *}$ & -0.677 & $0.970^{* *}$ & $0.940^{* *}$ & -0.017 & -0.516 \\
RP & $0.966^{* *}$ & 1 & -0.66 & $0.985^{* *}$ & $0.993^{* *}$ & 0.017 & -0.511 \\
WS & -0.677 & -0.66 & 1 & -0.772 & -0.691 & 0.736 & $0.978^{* *}$ \\
GR & $0.970^{* *}$ & $0.985^{* *}$ & -0.772 & 1 & $0.980^{* *}$ & -0.139 & -0.64 \\
CR & $0.940^{* *}$ & $0.993^{* *}$ & -0.691 & $0.980^{* *}$ & 1 & -0.369 \\
ED & -0.017 & 0.017 & 0.736 & -0.139 & -0.041 & 1 & 0.81 \\
HA & -0.516 & -0.511 & $0.978^{* *}$ & -0.64 & -0.551 & $0.842^{*}$ & $0.842^{*}$ \\
AL & $0.815^{*}$ & $0.844^{*}$ & -0.369 & 0.81 & 0.791 & 0.303 & 0.791 \\
\hline
\end{tabular}

** indicates that the two ecosystem services are significantly correlated at the 0.01 level; * indicates that the two ecosystem services are significantly correlated at the 0.05 level

positively correlated with water resources supply, and negatively correlated with other services.

The esthetic landscape in cultural services is negatively correlated with water supply and hydrological regulation. There is a positive correlation with other services, among which there is a significantly positive correlation with supply services (Fig. 3).

\section{Changes in ecosystem services and their relationship in the Poyang Lake Basin under scenario simulations}

\section{Value of ecosystem services in different scenarios}

Using the CA-Markov model, based on the land use information of 1995, 2005, and 2015, the land use information of the three scenarios (protection, planning, and development scenarios) in the Poyang Lake Basin in 2030 was simulated. The land use and its changes in different situations are shown in Table 8.

Figure 4 shows the spatial distribution of the ecosystem services value per unit area under different scenarios in 2030. In the three scenarios, the areas with high ecosystem service values in the Poyang Lake ecosystem are distributed in Poyang Lake and parts of the northern part of the basin. The areas with low ecosystem service value are more consistent with the distribution of farmland and construction land and are mainly distributed in the basin area and parts of the southwest. The median ecosystem service values are distributed in parts of the western part of the basin. The comparison of the protection, planning, and development scenarios indicates that as the development intensity increases, the ecosystem service value is reduced, and the medium- and low-value regions are

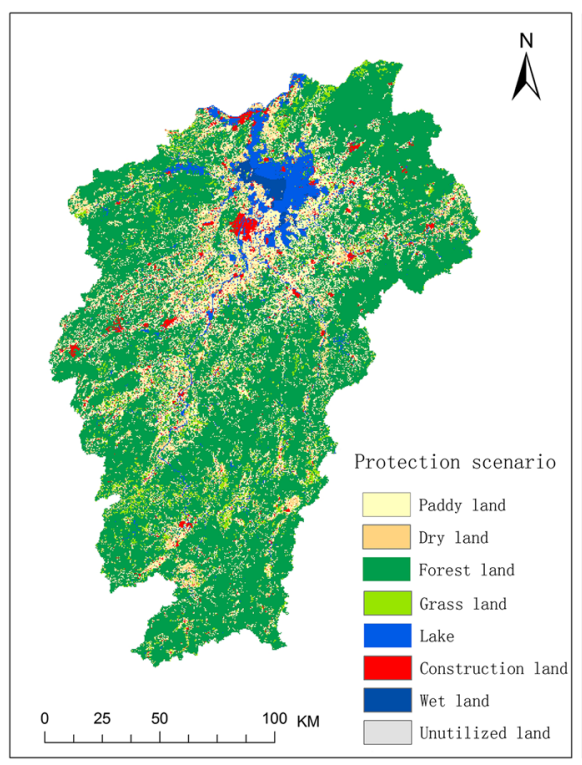

(a) Protection scenario

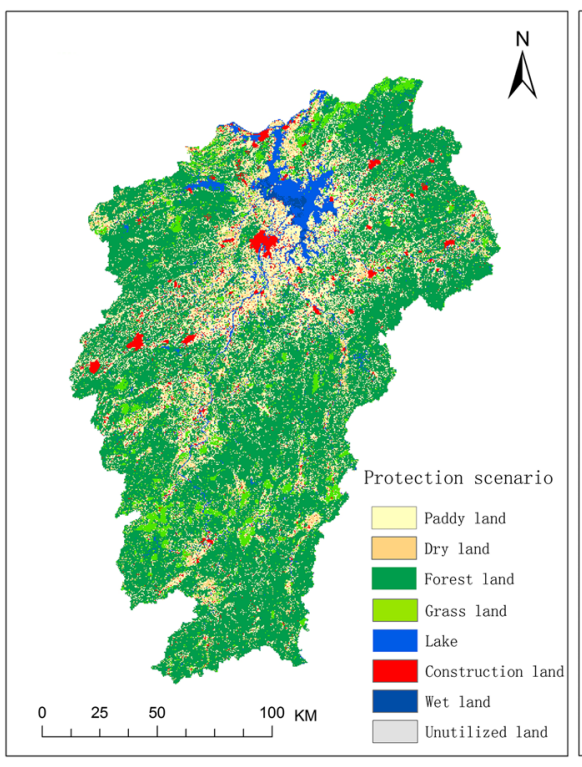

(b) Planning scenario

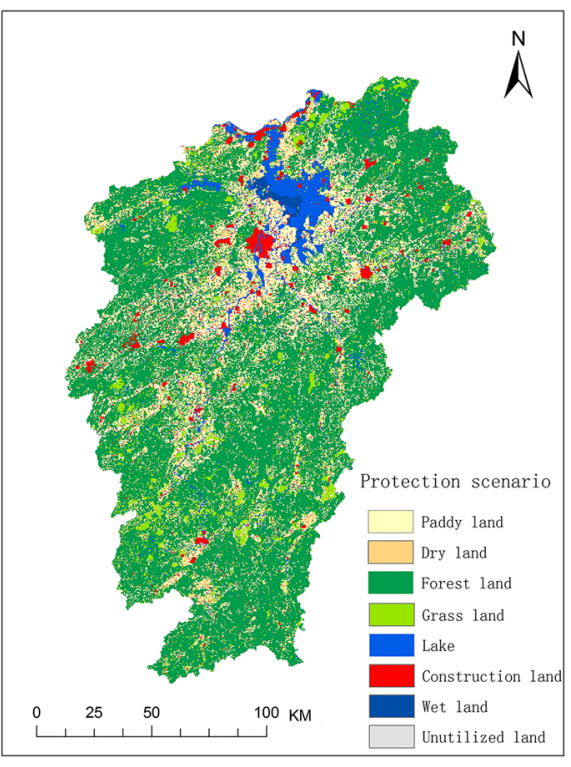

(c) Development scenario

Fig. 3 Simulated land use data under different scenarios 
Table 8 Proportion of land use types and their changes under different scenarios compared with 2015

\begin{tabular}{lll}
\hline & Protection scenario & Planning scenario \\
\hline Farmland & $22.66 \%(-3.82 \%)$ & $24.02 \%(-2.47 \%)$ \\
Forestland & $64.65 \%(+2.61 \%)$ & $61.85 \%(-0.20 \%)$ \\
Grassland & $4.52 \%(+0.07 \%)$ & $5.58 \%(+1.13 \%)$ \\
Lake & $4.78 \%(+0.67 \%)$ & $4.60 \%(+0.48 \%)$ \\
Wetland & $0.67 \%(+0.29 \%)$ & $0.55 \%(+0.17 \%)$ \\
Construction land & $2.69 \%(+0.18 \%)$ & $3.39 \%(+0.85 \%)$ \\
Unutilized land & $0.01 \%(+0.00 \%)$ & $0.01 \%(+3.06 \%)$ \\
\hline
\end{tabular}

"-" indicates that the area of the land category is decreasing compared to that in 2015 ; " + " indicates that the area of the land category is increasing compared to that in 2015

expanded, mainly in the western and northern parts of the basin. The high-value areas are mainly expanding in the central region, and the scope of new construction land is roughly the same (Table 9 ).

\section{Trade-off synergy between ecosystem services in different scenarios}

Based on the simulated ecosystem service value of the Poyang Lake Basin in 2030, the relationships between ecosystem services under three scenarios were analyzed. The results show that there are differences in the trade-off synergies between various ecosystems under different scenarios, and the degree of trade-offs also changes.
Under the protection scenario (Table 10), among the different ecosystem service values in the Poyang Lake Basin, 18 groups showed negative correlation and 46 groups showed positive correlation. Compared with 2015 (Table 7), the degree of synergy between ecosystem services increased from 59.3 to $71.9 \%$. Among them, the synergy between 18 groups of ecosystem services increased, the trade-off between 2 groups of ecosystem services decreased, 12 groups of ecosystem services changed from trade-off to synergy, and 6 groups of ecosystem services changed from synergy to trade-off. For example, there is a significant negative correlation between food production and other ecosystem services. Compared with 2015, the correlation coefficient increases, so the trade-off degree increases. Besides the significant negative correlation between purified environment and food production, there is a

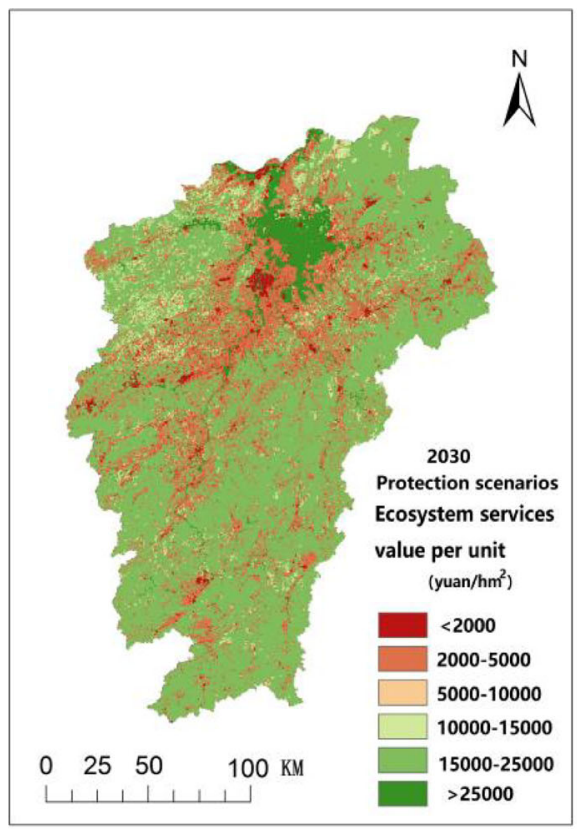

(a) Protection scenario

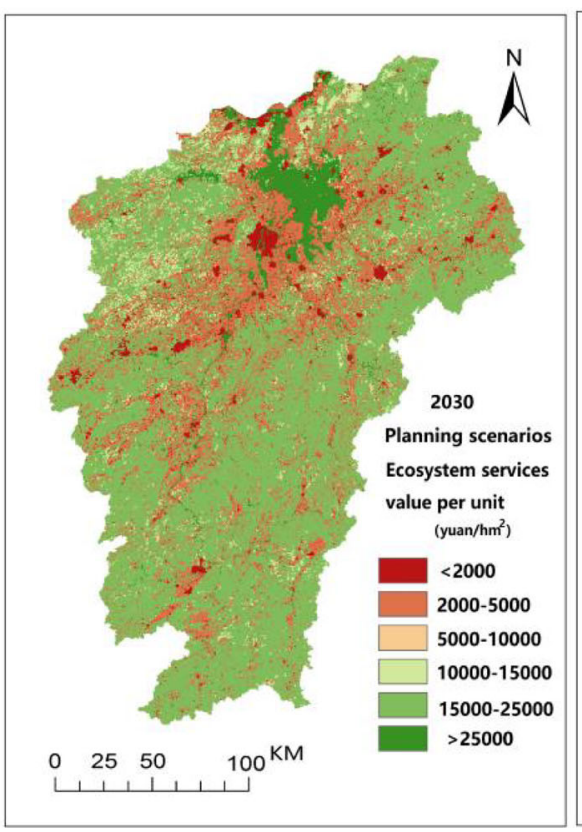

(b) Planning scenario

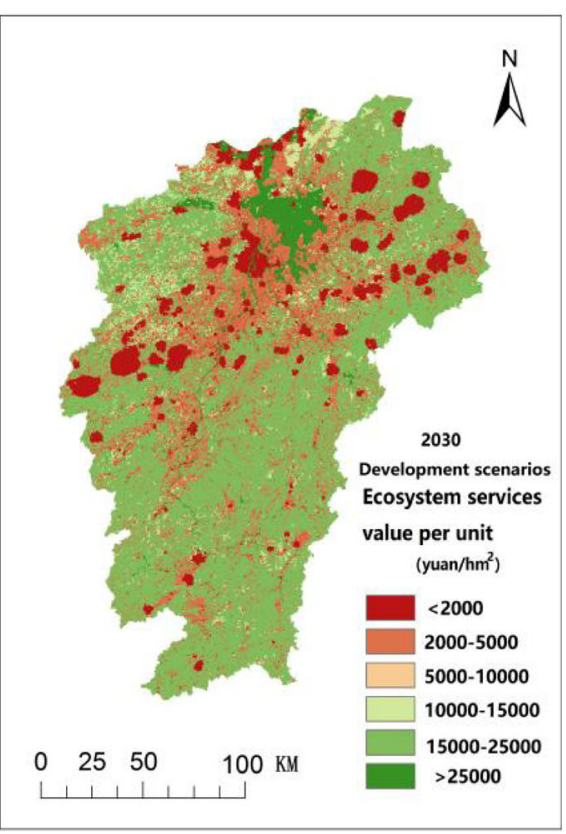

(c) Development scenario

Fig. 4 Ecosystem service value under different scenarios (unit: yuan/ha) 
Table 9 Ecosystem service values of the Poyang Lake Basin under simulated scenarios (unit: 100 million yuan)

\begin{tabular}{llll}
\hline & Protection scenario & Planning scenario & Development scenario \\
\hline FP & 54.83 & 55.50 & 52.96 \\
RP & 51.36 & 50.31 & 46.61 \\
WS & 19.72 & 16.99 & 13.05 \\
GR & 180.04 & 176.65 & 164.28 \\
CR & 474.64 & 461.53 & 424.89 \\
ED & 169.97 & 163.72 & 151.25 \\
HA & 903.63 & 885.28 & 811.52 \\
AL & 88.23 & 85.64 & 78.30 \\
Total & 2130.37 & 2080.17 & 1912.14 \\
\hline
\end{tabular}

positive correlation between purified environment and other ecosystem services, compared with 2015 , the correlation coefficient increases, so the degree of synergy increases.

Under the planning scenario (Table 11), 27 groups showed negative correlation and 37 groups showed positive correlation among different ecosystem service values in Poyang Lake Basin. Compared with 2015 (Table 7), there was no significant change in the degree of synergy between ecosystem services. Among them, the degree of synergy among eight groups of ecosystem services increased, and the trade-off among eight groups of ecosystem services increased. For example: water supply and a negative correlation relationship of ecosystem services system, compared to 2015, the correlation coefficient increases, so increasing the degree of trade-off; climate regulation and a negative correlation with the ecological system service relationship, the correlation coefficient is reduced; therefore, the degree of trade-off is reduced.

Under the development scenario (Table 12), among the different ecosystem service values in the Poyang Lake Basin, there was a negative correlation between the 28 groups and a positive correlation between the 36 groups. Compared with 2015 (Table 7), the synergy between ecosystem services decreased from 59.3 to $56.3 \%$. Among them, the trade-off between 18 groups of ecosystem services increased, the synergy between 16 groups of ecosystem services decreased, and the synergy between the four groups of ecosystem services became a trade-off relationship. For example, in the ecosystem service relationship which is negatively correlated with raw material production, the correlation coefficient increases compared with that in 2015 , so the trade-off degree increases. In the ecosystem service relationship, which is positively correlated with water resources supply, the correlation coefficient increases, so the degree of synergy increases.

In regional land planning, policy-makers often need to make predictions about ecosystem services and trade-offs through land use changes to provide scientific support for regional development (Cowling et al. 2008; Haines-Young 2009). In the research on trade-off relationships, the management of regional ecosystem services and the maximization of the synergy relationship of regional ecosystems are the ultimate goals. Figure 5 shows a comparison of ecosystem services and their trade-offs under different scenarios. We divided the simulation scenario into four scenarios: (1) the ES total and trade-offs exceeded 2015; (2) the ES exceeded 2015, and the trade-offs were lower than 2015; (3) the ES and trade-offs were lower than 2015; and (4) the ES is lower than 2015, and the trade-offs were higher than 2015. The second of these four cases is a better case than the other three, and the fourth is the worst case (Yang et al. 2018). As can be seen from Fig. 5, the total ES under the protection scenario is the highest and the trade-offs are the lowest. Under the development scenario, the total ES is the lowest, and the trade-offs are the highest. Between the planning scenario and the protection scenario, the total ES differs slightly, but the trade-offs differ greatly. Consequently, the protection scenario is better than the development scenario and the planning scenario, while the development scenario is worse than the other two scenarios.

Table 10 Trade-off synergy between ecosystem services in the Poyang Lake Basin under the protection scenario

\begin{tabular}{|c|c|c|c|c|c|c|c|c|}
\hline Related & FP & $\mathrm{RP}$ & WS & GR & $\mathrm{CR}$ & ED & HA & $\mathrm{AL}$ \\
\hline FP & 1 & $-0.883 * *$ & -0.739 & $-0.902 * *$ & $-0.958 * *$ & $-0.921 * *$ & $-0.913 * *$ & $0.916 * *$ \\
\hline $\mathrm{RP}$ & $-0.883^{* *}$ & 1 & 0.428 & $0.997 * *$ & $0.890 * *$ & 0.761 & -0.498 & $0.947 * *$ \\
\hline WS & -0.739 & 0.428 & 1 & 0.202 & -0.735 & 0.776 & $0.937 * *$ & -0.678 \\
\hline GR & $-0.902 * *$ & $0.997 * *$ & 0.202 & 1 & $0.988 * *$ & 0.716 & 0.71 & $0.944 * *$ \\
\hline $\mathrm{CR}$ & $-0.958 * *$ & $0.890 * *$ & -0.735 & $0.988 * *$ & 1 & $0.777 *$ & 0.662 & $0.920 * *$ \\
\hline ED & $-0.921 * *$ & 0.761 & $0.776^{*}$ & 0.716 & $0.777^{*}$ & 1 & $0.978 * *$ & $0.775 *$ \\
\hline HA & $-.913 * *$ & -0.498 & $0.937 * *$ & 0.71 & 0.662 & $0.978 * *$ & 1 & -0.418 \\
\hline $\mathrm{AL}$ & $0.916 * *$ & $0.947 * *$ & -0.678 & $0.944 * *$ & $0.920 * *$ & $0.775^{*}$ & -0.418 & 1 \\
\hline
\end{tabular}

** indicates that the two ecosystem services are significantly correlated at the 0.01 level; * indicates that the two ecosystem services are significantly correlated at the 0.05 level 
Table 11 Trade-off synergy between ecosystem services in the Poyang Lake Basin under the planning scenario

\begin{tabular}{lllllllrr}
\hline Related & FP & RP & WS & GR & CR & ED & HA \\
\hline FP & 1 & 0.171 & -0.428 & $0.837 *$ & -0.467 & $-0.924 * *$ & $-.928^{* *}$ \\
RP & 0.171 & 1 & -0.611 & 0.67 & $0.789 *$ & -0.088 & -0.143 \\
WS & -0.428 & -0.611 & 1 & -0.73 & -0.313 & 0.459 & 0.648 \\
GR & $0.837^{*}$ & 0.67 & -0.73 & 1 & 0.085 & -0.671 & $-0.810^{*}$ \\
CR & -0.467 & $0.789^{*}$ & -0.313 & 0.085 & 1 & 0.673 & -0.078 \\
ED & $-0.924^{* *}$ & -0.088 & 0.459 & -0.671 & 0.636 & 1 & 0.43 \\
HA & $-0.928^{* *}$ & -0.143 & 0.648 & $-0.810^{*}$ & 0.43 & $0.968^{* *}$ & $0.968^{* *}$ \\
AL & -0.502 & 0.673 & -0.078 & -0.019 & $0.887 * *$ & 0.719 & 0.719 \\
\hline
\end{tabular}

** indicates that the two ecosystem services are significantly correlated at the 0.01 level; * indicates that the two ecosystem services are significantly correlated at the 0.05 level

\section{Analysis}

\section{Changes in the values of ecosystem services and their drivers}

The value of ecosystem services in the Poyang Lake Basin from 1990 to 2015 showed an overall increasing trend. On the one hand, this trend was related to the annual increase in the equivalent factor, and on the other hand, it was related to the special ecological environment and human activities in the basin. The Poyang Lake Basin is one of the most important storage lakes for the Yangtze River. The ecological environment of the basin is related to the ecological security of the middle and lower reaches of the Yangtze River. Therefore, the ecological security of the basin has always been a concern for many people (Vörösmarty et al. 2010). Over the past 20 years, the "Mountain River and Lake Project" has been effectively implemented in the basin. The vegetation coverage of the basin has increased each year, and soil erosion control has also been effective, with an area of nearly 53,000 ha per year. On December 12, 2010, with the official approval of the "Poyang Lake Ecological Economic Zone Planning" by the State Council, the ecological construction in the basin increased to the national standards, which deepened the people's understanding of ecological environment protection and the various measures necessary to improve and protect the ecological environment, such as "Administrative Measures for Compensation Funds for Ecological Public Welfare Forests in Jiangxi Province," "Public Functional Area Planning in Jiangxi Province" and "Jiangxi Provincial Watershed" Ecological Compensation Measures (Trial), and "Establishment Implementation Plan for the Pioneering Zone of Ecological Civilization in Jiangxi Province." The implementation of these policies has greatly promoted the sustainable development of the ecological environment of the river basin, and the value of ecosystem services in the river basin has increased each year (Zhao et al. 2017; Liu et al. 2017a, b). The ecosystem service value of the Poyang Lake Basin is characterized by values that are low in the middle and high in the surrounding areas. From a regional perspective, the central region is the Poyang Lake Plain, which is active in social and economic

Table 12 Trade-off synergy between ecosystem services in the Poyang Lake Basin under the development scenario

\begin{tabular}{|c|c|c|c|c|c|c|c|c|}
\hline Related & FP & $\mathrm{RP}$ & WS & GR & $\mathrm{CR}$ & ED & HA & $\mathrm{AL}$ \\
\hline FP & 1 & $0.910^{* *}$ & 0.181 & 0.699 & -0.598 & -0.46 & -0.713 & 0.608 \\
\hline $\mathrm{RP}$ & $0.910 * *$ & 1 & -0.741 & 0.564 & $0.894 * *$ & -0.261 & -0.635 & $0.792 *$ \\
\hline WS & 0.181 & -0.741 & 1 & $-0.839 *$ & -0.629 & $0.839^{*}$ & $0.980 * *$ & -0.336 \\
\hline GR & 0.699 & 0.564 & $-0.839 *$ & 1 & 0.147 & -0.409 & -0.748 & 0.737 \\
\hline $\mathrm{CR}$ & -0.598 & $0.894 * *$ & -0.629 & 0.147 & 1 & -0.144 & -0.549 & $0.791 *$ \\
\hline $\mathrm{ED}$ & -0.46 & -0.261 & $0.839^{*}$ & -0.497 & -0.144 & 1 & $0.897 * *$ & 0.184 \\
\hline HA & -0.713 & -0.635 & $0.980 * *$ & -0.748 & -0.549 & $0.897 * *$ & 1 & -0.248 \\
\hline $\mathrm{AL}$ & 0.608 & $0.792 *$ & -0.336 & 0.737 & $0.791 *$ & 0.184 & -0.248 & 1 \\
\hline
\end{tabular}

** indicates that the two ecosystem services are significantly correlated at the 0.01 level; * indicates that the two ecosystem services are significantly correlated at the 0.05 level 
Fig. 5 Comparison of ecosystem services and their trade-offs in different scenarios

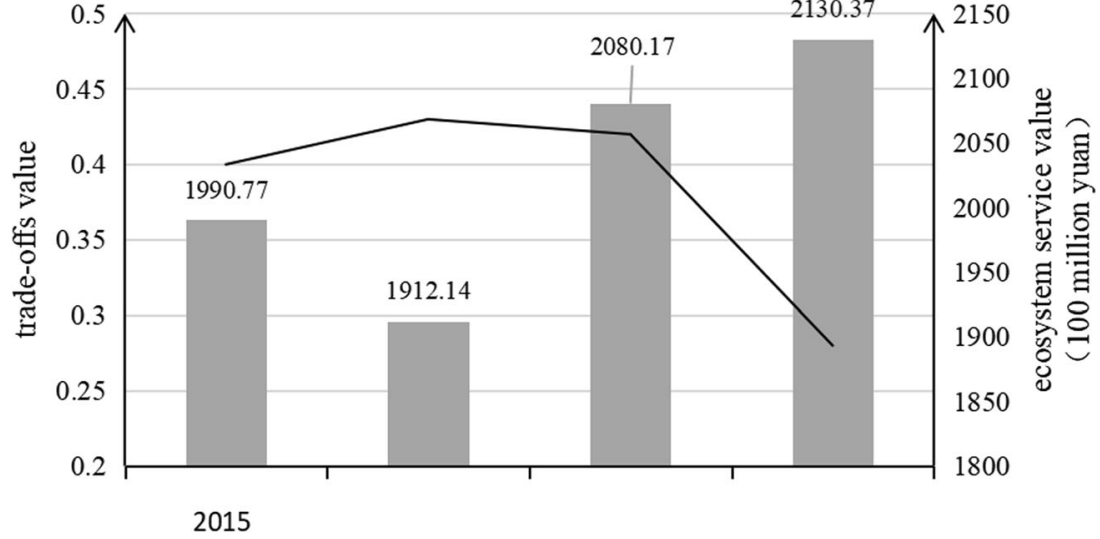

Overall ES — Trade-offs activities. The proportions of agricultural land and construction land are higher than those in other regions, while the proportions of forestland and grassland are lower than those in other regions, and agricultural use is low. The proportion of construction land continues to increase, and the proportions of forestland and grassland continue to decrease; thus, the value of ecosystem services is low. The mountainous and hilly areas outside the lake area have better ecological environments and high vegetation coverage. Therefore, the related adjustment services, high cultural service values, and high total ecosystem service values are also available (Zhu et al. 2017).

\section{Analysis of the causes of ecosystem trade-off coordination relationships}

The three types of ecosystem services in the basin are mainly coordinated. For the relationship between supply service and regulation service, the Poyang Lake Basin exhibits a significant synergy, which is due to the vast water surface of Poyang Lake, the dense vegetation of the wetlands, and the frequent exchange of heat between the lake and the surrounding water; thus, the ability to regulate the ecosystem is high (Cui 2004). At the same time, as the largest freshwater lake in China, Poyang Lake has a strong water storage function and a high water supply capacity. The wetland flora and fauna products in the lake are rich, and the raw material supply capacity is also strong. The two services promote each other, so the synergy is high. There is a significant synergy between the western and northeastern regions. These areas are mountainous and hilly areas. Forests are widely distributed throughout these areas and have high carbon storage. Forests play an active role in regulating the climate and simultaneously provide the raw materials needed by humans, such as wood and various precious herbs. The central part of the Poyang Lake Plain exhibits a strong trade-off relationship. The main agricultural land in this area is highly disturbed by humans.
Although the food supply capacity is high, the ecosystem adjustment ability is poor due to poor human farming practices; this is consistent with the findings of Zhang et al. and Zhao et al. (Zhang et al. 2018; Zhao et al. 2017). For the supply service and cultural service, except for the balance in the central area of the Poyang Lake Plain, the rest of the area exhibits a synergistic relationship. The trade-off area is more consistent with the distribution of agricultural land and construction land. These areas have strong supply capacity, but the esthetic landscape value is low. However, the mountainous and hilly areas have strong supplies of raw materials and high esthetic landscape values, so the synergistic relationship is significant in these areas. For the regulation service and cultural service, all areas in the river basin except for the central part exhibit a synergistic relationship. This pattern occurs because most of the areas with high regulation capacity are forest, grassland, and water areas, and the esthetic landscape values of these areas are high.

\section{Comparative analysis of the trade-off relationship of ecosystem services under different scenarios}

Under the protection scenario, the correlation between the ecosystem services value of the Poyang Lake Basin is increased compared with that of 2015 , and the degree of synergy among the ecosystem services is also increased. This finding indicates that the future ecological environment of the study area is gradually improved, the policy of returning farmland to forests and grassland is significant, the total value of the ecosystem services is increased, the degree of synergy of the system is also increased, the functions of the ecological environment are gradually enhanced, and the environmental effects tend to develop in a favorable direction.

Under the planning scenario, the relationship between the ecosystem services value and the degree of synergy and tradeoffs among ecosystem services in the Poyang Lake Basin did not change significantly compared with that in 2015 . Under 
this scenario, population and urban land use increased steadily, and ecosystem services also increased steadily. This shows that according to the current economic development and urbanization speed, environmental protection pressure still exists, but the expansion of construction land has been controlled, ecological land such as forests, grassland, and unused land has been continuously restored and increased, and cultivated land has gradually become balanced. The district has taken into account environmental improvements and ecological protection measures while developing the economy.

Under the development scenario, the trade-offs among ecosystem services in Poyang Lake Basin increased and the synergies decreased compared with those in 2015. Under the development scenario, human beings pursue the maximization of economic benefits and the rapid expansion of construction land, resulting in increasing conflicts among ecosystem services. This shows that a one-sided pursuit of high-speed economic development and the continuous compression of living space toward cultivated land, grassland, and unused land further intensifies the contradiction between humans and land, and promotes the protection of cultivated land. The doubling of pressure also led to environmental deterioration in the study area, threatening ecological security.

\section{Discussion}

In this study, the "equivalent factor method" was used to estimate the value of ecosystem services in the Poyang Lake Basin from 1990 to 2015. The trade-offs and synergies among ecosystem services in the study period were also analyzed, and the 2030 trends were simulated under three scenarios. The study used a more conventional model to measure the ecosystem services functions and found similar trends in the temporal and spatial distribution characteristics of ecosystem services in the Poyang Lake region during the study period [Liu et al. 2017a, b; Zhang et al. 2018; Zhao et al. 2017]; the results were highly consistent, indicating that the model used is highly scientific and applicable. Based on remote sensing and geographic information technology, this study analyzes the evolution characteristics and mechanisms of ecological land use from the perspective of the ecological services value, and combines a scenario analysis with a CA-Markov model for future land use change scenario simulation. It enriches the theory and practice of scenario analysis, and on the other hand broadens the application scenario of CA-Markov model. The study not only analyzed the past land use changes in the study area but also simulated the future land use patterns and ecosystem services trade-offs and synergies under different scenarios in order to reveal the ecological environmental response of future land use changes and promote the sustainable development of future regional ecosystem services.
In view of the key factors affecting the system, scenario analyses analyze the temporal and spatial dynamics of various ecosystem services by formulating a number of future scenarios that give priority to ecological protection or socioeconomic development, or both, to provide reference for formulating relevant ecological protection policies. Butler et al. (2013) assessed the trade-offs and synergies between water quality regulation services and 10 other services under four land use scenarios in the Great Barrier Reef region of Australia. Bai et al. (2011), based on the InVEST model, determined the trade-offs among agricultural production, hydropower production and water quality maintenance under five scenarios in the Baiyangdian area, Hebei Province, China, analyzing their land use optimization schemes. Yang et al. (2016) used the CA-Markov model to simulate three land use patterns, the planning scenario, the protection scenario, and the development scenario, for China's GuanzhongTianshui Economic Zone in 2030, analyzing the trade-offs under the different scenarios. The authors concluded that the ecosystem services provided under the protection scenario were the highest. Based on land use, this study sets three scenarios: the planning scenario, protection scenario, and development scenario, to study the dynamic changes in the ecosystem services value in the Poyang Lake Basin. On this basis, a quantitative analysis of the trade-offs and synergies among different ecosystem services was carried out using a correlation analysis. Finally, we showed that the protection scenarios could increase the value of ecosystem services and reduce the trade-off effects. From the perspective of maximizing the value of ecosystem services and minimizing the trade-offs among ecosystem services, the protection scenario was better than the other two scenarios. Therefore, for regional ecological environmental protection, the protection scenario should be used as an important guide to further implement policies for returning farmland to forests and grassland, increase the protection of forest land resources in the eastern and western mountainous hilly areas, and restore the lost ecological potential. At the same time, a farmland protection red line should be demarcated to ensure regional food security. In addition, increased investment should be made toward environmental protection, based on resource advantages, developing a green economy, and achieving sustainable regional development.

There are also some limitations to this study. For example, ecosystem services trade-offs and synergies were analyzed for the whole region, but ecosystem services trade-offs and synergies have scale effects. From the perspective of the supply side, the scale-dependent nature of ecosystem services comes from the scale effect of ecosystem function (Zhang et al. 2018). Some ecosystem services only play a role at the local scale, while others have a large spatial scope. From the demand side, the scale-dependent nature of ecosystem services is caused by the differences in service needs between different levels of consumers at different stages. Because the supply 
and demand of different ecosystem services are spatially inconsistent, the spatial transfer of ecosystem services will lead to different understandings of the trade-offs and synergies between different levels of stakeholders (Bohensky et al. 2006). Therefore, the trade-off and synergy relationship must also be scale dependent due to these regional differences ( $\mathrm{Li}$ et al. 2013). From the point of view of scenario model construction, this study only constructs three scenarios to study ecosystem services, and the optimal scenario is limited to these three scenarios. With future developments, it will be necessary to build a large number of schemes to analyze the trade-offs and synergies among ecosystem services under different future scenarios in order to select the most appropriate scenario according to the regional development, which will provide a solid basis for future planning. Scenario simulation of the ecosystem services value and its relationship is mainly based on relevant government policies, without considering the impact of changes in other factors on ecosystems (Lautenbach et al. 2019), such as climate change (Prather et al. 2013), demographic changes (shrinking/growing population, aging of population), behavioral changes (Tscharntke et al. 2012), and economic development (Banse et al. 2011; Campbell and Doswald 2009). Therefore, in future research, more reliable land use simulations should be combined with more factors to further study the evolution of trade-offs and synergies in the basin combined with ecosystem services.

Funding information This research was financially supported by the National Key Research and Development Program of China (2018YFC1506500), National Natural Science Foundation of China (41971402), and the Surveying \& Mapping and Geo-information Research in the Public Interest (201512026).

Open Access This article is licensed under a Creative Commons Attribution 4.0 International License, which permits use, sharing, adaptation, distribution and reproduction in any medium or format, as long as you give appropriate credit to the original author(s) and the source, provide a link to the Creative Commons licence, and indicate if changes were made. The images or other third party material in this article are included in the article's Creative Commons licence, unless indicated otherwise in a credit line to the material. If material is not included in the article's Creative Commons licence and your intended use is not permitted by statutory regulation or exceeds the permitted use, you will need to obtain permission directly from the copyright holder. To view a copy of this licence, visit http://creativecommons.org/licenses/by/4.0/.

\section{References}

Alcamo J, Vuuren DV, Ringler C, Cramer W, Schulze K (2005) Changes in nature's balance sheet: model-based estimates of future worldwide ecosystem services. Ecol Soc 10(2):19

Bai Y, Zhuang CW, Ouyang ZY et al (2011) Spatial characteristics between biodiversity and ecosystem services in a human dominated watershed. Ecol Complex 8(2):177-183
Banse M, van Meijl H, Tabeau A, Woltjer G, Hellmann F, Verburg PH (2011) Impact of EU biofuel policies on world agricultural production and land use. Biomass Bioenergy 35:2385-2390

Barbier EB, Koch EW, Silliman BR, Hacker SD, Wolanski E, Primavera J, Granek EF, Polasky S, Aswani S, Cramer LA, Stoms DM, Kennedy CJ, Bael D, Kappel CV, Perillo GM, Reed DJ (2008) Coastal ecosystem-based management with nonlinear ecological functions and values. Science 319(5861):321-323

Bennett EM, Balvanera P (2007) The future of production systems in a globalized world. Front Ecol Environ 5(4):191-198

Bennett EM, Peterson GD, Gordon LJ (2009) Understanding relationships among multiple ecosystem services. Ecol Lett 12(12):1394 1404

Bohensky EL, Reyers B, van Jaarsveld AS (2006) Future ecosystem services in a Southern African river basin: a scenario planning approach to uncertainty. Conserv Biol 20:1051-1061

Brauman KA, Daily GC, Duarte TK (2007) The nature and value of ecosystem services: an overview highlighting hydrologic services. Social Science Electronic Publishing 32(32)

Butler JRA, Wong GY, Metcalfe DJ et al (2013) An analysis of trade-offs between multiple ecosystem services and stakeholders linked to land use and water quality management in the Great Barrier Reef, Australia. Agric Ecosyst Environ 180:176-191

Byron C, Jin D, Dalton T (2015) An integrated ecologicaleconomic modeling framework for the sustainable management of oyster farming. Aquaculture 447:15-22

Campbell A, Doswald N (2009) The impacts of biofuel production on biodiversity: a review of the current literature. Cambridge, UK

Chisholm RA (2010) Trade-offs between ecosystem services: water and carbon in a biodiversity hotspot. Ecol Econ 69(10):1973-1987

Cord AF, Bartkowski B, Beckmann M et al (2017) Towards systematic analyses of ecosystem service trade-offs and synergies: main concepts, methods and the road ahead. Ecosystem Services 28:264-272

Costanza R, D'Arge R, De Groot R et al (1997) The value of the world's ecosystem services and natural capital. Word Environment 387(6630):253-260

Costanza R, De Groot R, Braat L et al (2017) Twenty years of ecosystem services: how far have we come and how far do we still need to go? Ecosystem Services 28:1-16

Cowling RM, Egoh B, Knight AT, O'Farrell PJ, Reyers B, Rouget M, Roux DJ, Welz A, Wilhelm-Rechman A (2008) An operational model for mainstreaming ecosystem services for implementation. PNAS 105(28):9483-9488

Cui LJ (2004) Study on functions of Poyang Lake wetland ecosystem. J Soil Water Conserv 18(2):109-113

Dai E, Wang X, Zhu J, Zhao DS (2016) Methods, tools and research framework of ecosystem service trade-offs. Geogr Res 35(06): $1005-1016$

Daily G (1997) Nature's services: societal dependence on natural ecosystems. Washington DC: Island Press, 1997

Daily GC, Polasky S, Goldstein J et al (2009) Ecosystem services in decision making: time to deliver. Social Science Electronic Publishing 7(1):21-28

Field CB, Behrenfeld MJ, Randerson JT, Falkowski P (1998) Primary production of the biosphere: integrating terrestrial and oceanic components. Science 281(5374):237-240

Finlayson M, Harris J, McCartney M, Lew Y, Zhang C (2010) Report on Ramsar visit to Poyang Lake Ramsar site, P.R. China 1-34

Fu BJ, Yu DD (2016) Trade-off analyses and synthetic integrated method of multiple ecosystem services. Resources Science 38(01):1-9

Guan DJ, Gao WJ, Watari K, Fukahori H (2008) Land use change of Kitakyushu based on landscape ecology and Markov model. J Geogr Sci 18(4):455-468

Haase D, Schwarz N, Strohbach M, Kroll F (2012) Synergies, trade-offs, and losses of ecosystem services in urban regions: an integrated 
multiscale framework applied to the Leipzig-Halle Region, Germany. Ecol Soc 17(3):22

Haines-Young R (2009) Land use and biodiversity relationships. Land Use Policy 26:S178-S186

Haines-Young RH, Potschin MB (2009): Methodologies for defining and assessing ecosystem services. Final Report 69 pp.

Higgins SI, Turpie JK, Costanza R et al (1997) An ecological economic simulation model of mountain fynbos ecosystems Dynamics, Valuation and Management 22(2):0-169

Hua D, Shao J, Wang J, Ming G, Wei C (2016) Land use driving forces and its future scenario simulation in the Three Gorges Reservoir Area using CLUE-S model. Acta Geograph Sin 71(11)

Hussain AMT, Tschirhart J (2013) Economic/ecological tradeoffs among ecosystem services and biodiversity conservation. Ecological Economics 93(Complete):116-127

Kain JH, LarondelleN HD, Kaczorowska A (2016) Exploring local consequences of two land-use alternatives for the supply of urban ecosystem services in Stockholm year 2050. Ecol Indic 70:615-629

Lautenbach S, Mupepele AC, Dormann CF et al (2019) Blind spots in ecosystem services research and challenges for implementation. Reg Environ Chang 2019:1-22

Li P, Jiang LG, Feng ZM, Yu XB (2012) Research progress on trade-offs and synergies of ecosystem services: an overview. Acta Ecol Sin 32(16):5219-5229

Li SC, Zhang GY, Liu JL, Zhu WB, Ma C, Wang J (2013) The tradeoffs and synergies of ecosystem services: research progress, development trend, and themes of geography. Geogr Res 32(8):1379-1390

Liu J, Li J, Qin K, Zhou Z, Yang X, Li T (2017a) Changes in land-uses and ecosystem services under multi-scenarios simulation. Sci Total Environ 586

Liu H, Yin J, Lin M, Chen XL (2017b) Sustainable development evaluation of the Poyang Lake Basin based on ecological service value and structure analysis. Acta Ecol Sin 37(8):2575-2587

Mcdonough K, Hutchinson S, Moore T, Hutchinson JMS (2017) Analysis of publication trends in ecosystem services research. Ecosystem Services 25:82-88

Millennium Ecosystem Assessment (2005) Ecosystems and human wellbeing: synthesis. World Resources Institute, Washington, DC

Naidoo R, Balmford A, Costanza R, Fisher B, Ricketts TH (2008) Global mapping of ecosystem services and conservation priorities. Proc Natl Acad Sci 105(28):9495-9500

Nelson E, Mendoza G, Regetz J et al (2009) Modeling multiple ecosystem services, biodiversity conservation, commodity production, and tradeoffs at landscape scales. Front Ecol Environ 7(1):4-11

Pandeya B, Buytaert W, Zulkafli Z et al (2016) A comparative analysis of ecosystem services valuation approaches for application at the local scale and in data scarce regions. Ecosystem Services S2212041616304259

Peng J, Hu XX, Zhao MY, Liu YX, Tian L (2017) Research progress on ecosystem service trade-offs: from cognition to decision-making. Acta Geograph Sin 72(6):960-973

Prather CM, Pelini SL, Laws A, Rivest E, Woltz M, Bloch CP, del Toro I, Ho CK, Kominoski J, Newbold TA, Parsons S, Joern A (2013) Invertebrates, ecosystem services and climate change. Biol Rev Camb Philos Soc 88:327-348

Rodríguez JP, Douglas BT, Bennett EM et al (2006) Trade-offs across space, time, and ecosystem services. Ecology and Society 11(1): art 28

Saeed K (1986) The dynamics of economic growth and political instability in developing countries. System Dynamics Review 2(1):20-35

Shankman D, Keim BD, Song J (2006) Flood frequency in China's Poyang Lake Region: trends and teleconnections. Int J Climatol 26(9):1255-1266
Sun X, Li F (2017) Spatiotemporal assessment and trade-offs of multiple ecosystem services based on land use changes in Zengcheng, China. Sci Total Environ 609:1569

Tallis H, Polasky S (2009) Mapping and valuing ecosystem services as an approach for conservation and natural-resource management. Annals of the New York Academy of Sciences 1162(1), 265-283.

Tscharntke T, Clough Y, Wange TC et al (2012) Global food security, biodiversity conservation and the future of agricultural intensification. Biol. Conserv. 151:53-59

Tu XS, Long HL (2015) Spatial patterns and dynamic evolution of ecosystem service values in Poyang Lake Region from 2000 to 2010. Resources Science 37(12):2451-2460

Vörösmarty CJ, Mcintyre P, Gessner M (2010) Global threats to human water security and river biodiversity. Nature 467(7315):555-561

Wang DH, Zhang LQ, Guan YJ (2007) Population expansion of Spartina alterniflora and Phragmites australis at Jiuduansha, Shanghai based on cellular automata model. Chinese Journal of Applied Ecology 18(12):2807-2813

Wang P, Zhang L, Li YJ et al (2017) Spatio-temporal characteristics of the trade-off and synergy relationships among multiple ecosystem services in the Upper Reaches of Hanjiang River Basin. Acta Geographica Sinica 72(11):2064-2078

Willemen L, Hein L, Mensvoort MEFV, Verburg PH (2010) Space for people, plants, and livestock? Quantifying interactions among multiple landscape functions in a Dutch rural region. Ecological Indicators 10(1), 0-73.

Wilson CL, Matthews WH (1970) Mans impact on the global environment: assessment and recommendations for action. Report of the Study of Critical Environment Problems (SCEP) 1970. MIT Press, Cambridge Massachusetts, p 1970, 319 p

Xie GD, Zhen L, Lu CX (2008) Expert knowledge based valuation method of ecosystem services in China. J Nat Resour 23(5):911-919

Xie GD, Zhen L, Lu CX et al (2010) Applving value transfer method for Eco-service valuation in china. Journal of Resources and Ecology 1(1):51-59

Xie GD, Zhang CX, Zhang LM, Chen WH, Li SM (2015) Improvement of the evaluation method for ecosystem service value based on per unit area. Journal of Natural Resources 30(08):1243-1254

Xie HL, Yao G, He YF, Zhang DB (2018) Study on spatial identification of critical ecological space based on GIS: a case study of Poyang Lake Ecological Economic Zone. Acta Ecol Sin 38(16):5926-5937

Xu JH (1996) Mathematical methods in modern geography. Higher Education Press.

Yang XN, Zhou ZX, Li J, Fu X, Mu XM, Li T (2016) Trade-offs between carbon sequestration, soil retention and water yield in the Guanzhong- Tianshui Economic Region of China. J. Geogr. Sci 26(10):1449-1462

Yang S, Zhao W, Liu Y, Wang S, Wang J, Zhai R (2018) Influence of land use change on the ecosystem service trade-offs in the ecological restoration area: dynamics and scenarios in the Yanhe watershed, China. Science of the Total Environment 644:556-566

Zhang LG, Bao BF, Dong L (2018) Spatial and temporal pattern evolution of grain yield and spatial heterogeneity of driving factors in Poyang Lake. Eco Economic Economic Geography 38(2):154-161

Zhao ZG, Yu D, Han CY, Wang KR (2017) Ecosystem services value prediction and driving forces in the Poyang Lake Eco-economic Zone. Acta Ecol Sin 37(24):8411-8421

Zhu Z, Zhong Y, Yu XU (2017) The study on the evolution of ecosystem service value in Poyang Lake Basin. Journal of Jiangxi Normal University 41(05):538-545

Ziv G, Baran E, Nam S, Rodriguez-Iturbe I, Levin SA (2012) Trading-off fish biodiversity, food security, and hydropower in the Mekong River Basin. Proceedings of the National Academy of Sciences 109(15):5609-5614 